\title{
A democratised market? Development of South Africa's daily newspapers 1990 - 2006
}

\author{
Tobias Bauer
}

\begin{abstract}
This article looks at the development of the South African daily newspaper market between 1990 and 2006. The leading interest is to find out whether the market was able to develop from its apartheid-trenched roots, and in which areas the market is still influenced by its specific past. The market determinants, namely participants, growth, entrance barriers, distribution, readership, economic and editorial concentration, will be scrutinised over the 16 years. The relevant political, economical and legal background and the transformations taking place in these areas will be articulated. The data will reveal that by growing more and more, especially since the turn of the century, the market enables itself to break free from its old structure. This is mainly due to the successful introduction of new papers which break with the traditional orientation of South African papers towards a wealthy readership and thus win new readers for the product newspaper in general.
\end{abstract}

\section{Apartheid, newspapers and media policy}

The control of information via the media was important in the implementation and preservation of apartheid. The government did not want the Blacks to be informed about black leaders and politics; neither should the international community be informed about the injustices of apartheid. The regime applied a variety of laws to secure agreeable reporting and influenced media opinion by simply operating the media themselves (Hachten \& Giffard, 1984:113-124).

In its attitude towards the press, the apartheid regime revealed two differing faces: towards the English-language press the regime was very coercive, for it regarded the English-language press as its greatest enemy in the country (Hachten \& Giffard, 1984:3). Financed by mining houses, inspired by the English tradition of free press, the government and the Englishlanguage press had diametrically opposed views of the role of the press. Towards the Afrikaans press the relation was intimate from the beginning, because all Afrikaans papers were founded with the intention to advance the Afrikaner cause. Party officials were often editors of the papers. The Afrikaans press was in their own understanding a party press, divided only in support whether for the Cape or the Transvaal branch of the NP. More than a hundred laws were enacted regulating accessibility of information and the possibilities of publication. The most important laws concerning the print media were: 
- the Suppression of Communism Act, which made the publication of anything said or written by a banned person an offence

- the Terrorism Act, which allowed indefinite detention of journalists

- the Official Secrets Act, which proscribed the publication of any security matter

The government had the power to shut down newspapers completely, as it did in 1977 (World and Weekend World) and again in 1981 (Post and Weekend Post).

\section{The daily newspaper market 1990}

The South African daily newspaper market has multiple divisions: between Afrikaans- and English-language dailies (nowadays, there is also one published in isiZulu); between the cities and the countryside; and between the cities themselves. To understand the functioning of the market, I examine the following market determinants: participants, growth, entrance barriers, distribution, readership, economic and editorial concentration.

\section{Participants}

For the year 1990, the Audit Bureau of Circulation (ABC) lists 17 daily newspapers. These papers were published in:

- Johannesburg: The Sowetan, The Star, Business Day, Beeld and The Citizen

- Cape Town: Cape Argus, Cape Times and Die Burger

- Pretoria: Pretoria News

- Durban: Natal Mercury and Daily News

- Port Elizabeth: EP Herald and Evening Post

- East London: Daily Dispatch

- Kimberley: Diamond Fields Advertiser

- Bloemfontein: Die Volksblad

- Pietermaritzburg: The Witness

The Business Day is not of concern for this analysis, because it is a newspaper mainly concerned with economics and therefore differs profoundly from the 16 other, general interest papers. All 16 daily papers under supervision were mainly regional in distribution. The nationwide newspaper market was built only by weeklies or Sunday papers.

\section{Growth}

For the years preceding 1990 no complete data on circulation could be found. The only reliable numbers available for the 1980s are in Hachten et al (1984:267). They write that 21 dailies in 1982 had a combined circulation of 1,400,000. According to Hachten et al, average circulation was about 60,000 in 1982 . Although these figures are not representative, they can be indicative for an overall market development between 1982 and 1990.

A comparison shows that the daily market shrinks between 1982 and 1990. Circulation decreases from 1,400,000 to $1,263,471$ in January-June 1990. This represents a negative growth of 10.8 percent. Average circulation, yet, has not diminished: in the first half of 1990 it is 78,966. This amounts to a growth of the dailies' average circulation of 31.6 percent: the market gets narrower and the surviving participants profit from that development. Of course these results should be taken with a grain of salt, due to the vagueness of sources. 


\section{Entrance Barriers}

Entrance barriers can be formed by economic and political factors. The first political entrance barrier in 1990 surely is the Newspaper Registration Act of 1971, ruling that every newspaper has to register with the Ministry of Home Affairs and to pay a registration fee. Another political contribution to barring the market is the support of the two Afrikaans publishing houses, Perskor and Nasionale Pers, by the government. This support (mainly via nonnewspaper printing orders) enabled Perskor to run Die Transvaler at a loss (Jackson, 1993:94), just as it would be able to run The Citizen at a loss later (Jones, 2002:238).

Most prominent among the economic factors is the continued decline of the level of advertising for newspapers in the 1980s. Jackson (1993:7) writes that '[d]aily and weekly newspapers' share of the total amount spent on advertising dropped from 46.1 percent in 1975 to 29.4 percent in 1985 .'

But not only did newspapers' share sink, the overall level of advertising spending dropped continuously through the 1980 s and especially since the state of emergency was called out in 1985.

Another economic factor was the calculation of the big four publishers Argus, TML, Nasionale Pers and Perskor that they should not publish a further paper, because they would inevitably have set up a concurrent to their already existing products. After the Press Wars in the early 1980s, Johannesburg Consolidated Investments (JCI), a subsidiary of AngloAmerican and the major shareholder of both Argus and SAAN/TML, ruled that no more fights for new terrain between papers of either house would occur (Tomaselli \& Tomaselli, 1987:78); Perskor and Nasionale Pers have had a similar battle with similar results before (Muller, 1987:118-140).

Last but not least, because of the dominance of the big four, no independent publisher wanted to launch a new paper. History had shown that independent papers would be rapidly swallowed by one of the dominant publishers, as seen with the Bantu press, for example.

\section{Distribution}

The distribution of newspapers in 1990 is clearly arranged. All daily papers are regional in distribution. Each circulates in its place of publication and a comparatively small surrounding area. The reasons for this regional distribution are two-dimensional: first, South Africa is a highly urbanised country, and the urban centres are separated by large distances. Second, a more than regional distribution of a paper is not furthered by the ownership structure, as shown already.

\section{Readership}

Until the 1970s, newspapers were produced for a white audience. In the 1980s some liberal newspapers actively targeted black readerships, but this was too early for the market: advertisers regarded a huge proportion of black readers as a handicap. At the end of the 1980s, editors and publishers realised that Blacks would be the future main readership due to their numerical majority, transforming soon into a political majority as well. Additionally, average black income was rising steadily since the 1970s and thus increasing Blacks' attractiveness for advertisers. Furthermore, not only was black readership and spending power growing continually, white daily readership had been in constant decline since the 1960s (Hachten et al, 1984:270). Readership figures for the year 1990 are not available. 


\section{Economic concentration}

Of South Africa's 16 daily newspapers in 1990, 14 were in possession of the big four:

- Nasionale Pers owned Beeld, Die Burger and Die Volksblad

- Perskor owned The Citizen

- Argus owned Cape Argus, Daily News, The Star, Pretoria News, Natal Mercury, Diamond Fields Advertiser and The Sowetan

- TML owned Cape Times, EP Herald and Evening Post

The Witness and Daily Dispatch were independently owned.

Overall circulation of these 16 papers in the period January to June 1990 was $1,263,471$

copies. Of these, Perskor's Citizen contributed 140,435, equalling 11.1 percent of daily newspaper circulation. Nasionale Pers' three dailies had a combined circulation of 207,324, which is correspondingly 16.4 percent of total circulation. Argus' seven papers had a combined circulation of 733,506, a number that gives Argus a 58 percent share. TML's three papers had a combined circulation of 117,035 , which equals 9.3 percent. The two independent papers Daily Dispatch and The Witness had a circulation of 36,570 and 28,601 in 1990, giving them 2.9 percent and 2.3 percent accordingly.

These figures show an enormous level of concentration. Argus Newspapers is in a monopoly position, publishing 58 percent of daily circulation. This monopoly is even more pronounced when considering two facts: first, the market is divided into English-language and Afrikaanslanguage papers, making Argus' position in the English-language market even more threatening, as Argus publishes 69.4 percent of English-language dailies' circulation. Second, domination further increases when regarding that Anglo and JCI have the majority in both Argus and TML. It can be assumed that Anglo thus controls 67.3 percent of overall daily circulation, and 80 percent of the English-language circulation. These figures are extraordinarily high.

Of course, when one splits the daily newspaper market into language markets, the Argus' domination of the English market is still topped by Nasionale Pers' total monopoly of the Afrikaans daily market in 1990.

\section{Editorial concentration}

Editorial concentration in 1990 is very high. The Afrikaans dailies are controlled by publishers which are politically and economically linked to the government. According to Tomaselli et al, (1987:60), this is also somewhat true for the English-language press: because of the concentrated ownership of the English-language press in the hands of the mining economy, namely Anglo, interests coincide between the government and the owners of the press and thus opposition against apartheid is restricted.

A coalition between government and business was especially discernible in papers neglecting to cover political violence in a way that would have confronted Whites with the truth about apartheid's injustices. Commercial papers did not report until the late 1980s the circumstances under which black people had to suffer during apartheid; high economic concentration thus also puts a barrier to editorial competition.

But not only commercial factors were responsible for the high concentration. Obviously the 
set-up of the newsrooms was contributing to the one-sidedness of reporting. Especially in the Afrikaans dailies, but also in the English-language ones, non-whites were drastically underrepresented and under the editorial control of white colleagues and superiors.

Of course, one has to keep in mind that the publishers always had to think about two markets: Even if an audience was there for a newspaper dealing with the political concerns of the nonwhite majority, there would not have been customers in the advertising market for such a paper.

We have seen that the structure of the daily newspaper market in 1990 is determined by apartheid: the influential big publishers are all creatures of centuries of white minority rule: Nasionale Pers and Perskor are bound to the NP; Argus and TML were furthered by the racist politics, as English-language entrepreneurs knew their economic well-being would be protected by the Afrikaners since the building of the Union of South Africa in 1910. The daily newspaper market in 1990 is stagnant, highly concentrated, has extremely high entry barriers, is located in the urban centres, but has slowly started to cater to black readers. The following part will clarify to which extent these characteristics still describe the South African daily newspaper market in 2006, that is, to which extent the market is still influenced by structures of the apartheid era.

\section{Consequences of the democratisation for the print media}

With South Africa's democratisation, the print media were finding themselves in a liberalised society. Most important for them were the changes in the fields of law and economics.

\section{Constitutional law}

The most important right for media guaranteed by the Constitution is Freedom of Expression (section 16), followed by Freedom to Information (section 32). But not only does the Constitution give Freedom to Information such high status, it goes even further by section $32 / 1 / \mathrm{b}$, which says that information held by private bodies must be made accessible if necessary for the execution or protection of any rights of the person making the request. Possible conflicts with other rights, like section 14 (privacy) or 22 (freedom of trade), are regulated by section 36. It was envisaged that the right to Freedom to Information would be deepened and specified by enacting legislation.

\section{Statutory law}

In February 2000 the Parliament passed the Promotion of Access to Information Act (Act 2 of 2000), deepening the constitutional Right to Information. The Newspaper Registration Act was abolished with the passing of the Imprint Amendment Act in October 1994 (Märlender, 2000:74). These acts revised some of the repressing legislation created by the apartheid state. But statutory legislation in South Africa is not always furthering media freedom. Most threatening of the apartheid-derived statutory legislation for the media is section 205 of the Criminal Procedure Act (Act 56 of 1955). This section allows the imprisonment of journalists if they refuse to disclose their information sources on request by a court. Although the government ordered police to avoid using it in 1997 (http://www.southafricanewyork.net/consulate/news.htm\#history) after the Constitutional Court ruled section 205 unconstitutional in 1996 (Ndlela, 2003:245), the section was still used. In the democratised South Africa, whistleblower protection is still not fully realised. The introduction of the 
Protected Disclosures Act (Act 26 of 2000) did not alter this. Many observers regard the introduction of The Protection of Constitutional Democracy Against Terrorist and Related Activities Act in 2004 as just as critical. This law compels all citizens, including journalists, to report all information possibly related to terrorist activity to the authorities. This law 'will impede investigative reporting and compromise the independence of journalists' (htttp://www.cpj.org/attacks04/africa04/south.html). Another new law important for the print media is the Independent Broadcasting Authority Act (Act 153 of 1993), which regulates cross-media ownership. It states that enterprises may not own broadcasters and newspapers together in an area where both have a dominant market share.

\section{Common law}

With the democratisation, many components of common law were nullified because they were in conflict with the new Constitution. Concerning media, especially the conflict between the right to freedom of expression and the right to reputation was rekindled. During apartheid, courts had generally given the right to reputation the upper hand over media's right to publish information. But in 1998 this changed: The Supreme Court of Appeal decision in Bogoshiv National Media Ltd and others 1996 (3) SA 78 (W) expanded and set new, justifiable limits to freedom of expression. By such decisions, common law strengthens media freedom and its watchdog role against government attacks.

After the democratisation, the ANC refuted all sceptics and embarked on a liberal economic policy with the RDP (Reconstruction and Development Programme) and the succeeding GEAR (Growth, Employment and Redistribution) programme. These were typical exponents of neoliberal policies employed all over the globe in democratising countries in the $20^{\text {th }}$ century. According to Lewis (2001:3) what separates South Africa from other democratising countries is that:

South Africa already had a core economy with all the foundations and infrastructure of a market system [...] the challenge was not to create a market economy overnight, but rather to find mechanisms for making the existing market economy more competitive, while creating instruments to ensure that those who had been excluded could be integrated.

In 2004, the government launched a new macroeconomic master plan termed Black Economic Empowerment (BEE).

\section{Deregulation of the market}

The most important consequence of the ANC's economic policy for the newspaper publishers was the deregulation of the market. The ANC did not only privatise national companies, but also reduced government's influence. In the print sector, the ANC ended state support for single competitors. The numerous barriers restricting Blacks from advancement and ensuring job reservation for Afrikaners also fell. Of course there still are socioeconomic factors favouring Whites and discriminating Blacks, but this is no more politically intended.

With the democratisation, Blacks can now purchase shares of the big publishers or start their own publishing houses. Of course, black investment was formerly not only limited or prevented by law, but also by the institutionalised poverty Blacks had been suffering for generations. 
Directly linked to the deregulation of the market is its internationalisation. The protection of national companies is minimised in exchange for more international competitiveness. This process, implemented mainly through GEAR, led to the unbundling of domestic conglomerates and to an increased ownership of assets by international agents. Tony O'Reilly's Irish-based Independent group took control over Argus in the 1990s.

\section{Affirmative Action}

The ANC needed to find means of redistribution to satisfy its voters. The option most compatible to its new-found liberal economy philosophy was Affirmative Action (AA). AA in the South African context can be defined as policy measures established to compensate past injustices of discrimination by positively discriminating the former victims now. As written in the Constitution of the Republic of South Africa 1996, $\S 9 / 2$ this policy is protected and demanded by the Bill of Rights of the Constitution of 1996.

To implement AA, the government enacted the Employment Equity Act (EEA) in October 1998, consisting of two parts: in the first part, discrimination on racial, religious, sexist or other grounds is forbidden; the second part contains the Affirmative Action programme. Its regulations are valid for all authorities and employers with more than 50 employees and thus for all daily papers. For the media, AA was not only a legal imperative, but also a professional one: to get all the important stories, a paper cannot rely on a purely white staff.

The implementation of AA in the media sector was two-edged. The state-run broadcasting service SABC had run a very successful programme (Hahne, 2002:222). The print publishers had more difficulties. While the Afrikaans-language newspapers are criticised for not running proper AA programmes in the newsroom, the English-language press is attacked for their ownership and management structures. The whiteness of the papers is a recurring point of critique for government members (Hahne, 2002:233; Kolbe, 2005:161-164; Vapi, 1999:23). But what should not be forgotten in the discussion about white ownership of publishers is the argument brought forward by Southall (2006:461): 'the most formidable barrier to a significant increase of black ownership within the corporate sector has been blacks' lack of capital.'

All in all, notwithstanding a less than optimal statutory legislation, preconditions are good for the market to depart from its apartheid-derived structures. Now the question is: has the market made use of these promising conditions, or did it remain determined by its apartheid past?

\section{The daily newspaper market 2006 \\ Participants}

The newspaper market in 1990 had 16 participants. This remained unchanged during the transition and longer. Only in 2000, there is the first change when the Evening Post is terminated. In 2001 the EP Herald is renamed The Herald, its publisher TML becomes Johnnic Publishing. In 2002, Naspers launches the Daily Sun, a Gauteng-based tabloid that is about to conquer the daily market; Independent Newspapers (INP) launches Isolezwe, the first daily in a native African language, namely isiZulu. On October $7^{\text {th }}, 2003$ the Nigerian Leaders \& Company launches a South African edition of its Nigerian This Day, which is suspended only a year later. INP publishes another new tabloid since March $16^{\text {th }}, 2005$ : the Daily Voice. In April, Naspers transforms its successful weekly Kaapse Son into Son, an Afrikaans daily 
for Cape Town and the Western Cape, and launches the tabloid Nova on September $19^{\text {th }}$ in Johannesburg. Yet, expectations are not fulfilled and Nova is terminated in February 2006. In summary, the South African daily newspaper market in 2006 has 19 participants. Compared to the starting point of this analysis, the total number has increased by three. One daily did not survive. Six new titles are launched in the period under observation; only four of them have found their niche.

\section{Growth}

The ABC provides precise data for newspaper circulation in South Africa since 1990. From 1990 to mid-1994, overall daily circulation remains at a level between 1,200,000 and 1,300,000. Until January-June 2001, when circulation reaches the lowest level in the 16 years under analysis at 1,060,515, the market does not grow.

From late 2002 onwards, circulation rockets up: slight growth of 3 percent in the second half of 2002 is followed by an 11.4 percent upsurge in January-June 2003, amounting to a circulation of $1,221,078$. This trend is continued with growth rates of 1.9 percent, 7.2 percent, 2.5 percent and again 7.2 percent in the following half-years. In the second half of 2005 , growth slows down, resulting in a circulation of 1,463,666. But in the first six months of 2006 growth is positive again, and the $\mathrm{ABC}$ reports the circulation of 1,499,968, an all time high. In effect the daily market has grown even stronger since early 2005, due to the introduction of the Daily Voice and the Son (for both dailies no reliable circulation figures were available). Where does that growth come from?

Most of the overall growth is due to the launch of the Daily Sun. Shortly after its introduction, circulation is at 71,742, and the Sun keeps growing with a circulation of 452,368 in the period January-June 2006. The other daily launched in 2002, Isolezwe, is also operating successfully. Its first circulation figure was at 27,475. Circulation has risen steadily since, reaching 97,370 in the period January-June 2006. This is a huge success for a daily published in isiZulu: prior to the democratisation, many would not have thought it possible to publish a daily in a native African language, because apparently 'reading is a culture that is generally foreign to African communities, especially in South Africa' (Maake, 2002:152; Vapi, 1999:24).

When taking a look at the development of each daily separately, three different trends emerge:

1. Of the 19 dailies on the market in 2006, seven have lost circulation significantly since 1990: Cape Argus, Cape Times, The Citizen, Daily News, Mercury, Sowetan and The Star

2. Seven others have kept their circulation at the level of 1990: Beeld, Daily Dispatch, Diamond Fields Advertiser, Herald, Pretoria News, Volksblad and The Witness

3. Five have grown considerably in the sixteen years: Die Burger, Daily Sun, Isolezwe, Son and Daily Voice

These trends are contradictory on the first impression, but show a specific pattern when examined thoroughly: with the exception of Die Burger, all newspapers recording growth are newcomers. All eight papers with distinct losses are English-language dailies. The Afrikaanslanguage dailies have fared much better by either growing or at least retaining their circulation of 1990. Jones (2002:464) offers a possible explanation for this: ' $\{$ t] ]he Afrikaans press $[\ldots]$ was handed an expanded constituency - perhaps uniquely in the world, it benefited 
from an exodus of broadcast audiences to newspapers.'

A surprising trend is that most movement in the market is in the cities where newspapers were in a competition situation in 1990: of the seven circulation-losing dailies three are published in Johannesburg/Gauteng, two each in Durban and Cape Town. The five dailies that grow in the period under analysis are also published in and for Johannesburg/Gauteng, Cape Town and Durban. Of the seven papers that held their circulation, six hold a monopoly in their city: The Volksblad (Bloemfontein), the Pretoria News (Pretoria), the Herald (Port Elizabeth), the Diamond Fields Advertiser (Kimberley), the Witness (Pietermaritzburg) and the Daily Dispatch (East London).

This pattern of stability in monopoly situation and positive or negative growth in competition situations is only broken by Beeld, which preserved its circulation despite being published in Johannesburg. But then, Beeld is arguably in a monopoly situation, being the only Afrikaanslanguage daily published in Johannesburg. Thus, the pattern is upheld.

\section{Entrance barriers}

The political entry barriers to the daily newspaper market fell with the democratisation. The barriers posed by economic factors have equally decreased or disappeared. The reduction of money spent for advertising in general and especially for newspapers in the 1980s reversed in the 1990s. Total advertising spending grows continually in the period under analysis, between 1991 and 2005 spending increases by 770 percent (South African Media Facts 2002:11; South African Media Facts 2006:11). Over the same period, advertising spending on daily newspapers grows by 605 percent.

The barrier erected by the domination of the big four did not lower. Despite the selling of papers to new competitors like NAIL, the selling of shares in single papers and temporary entrances, in 2006 the market is controlled totally by four companies. Each daily paper published in South Africa in 2006 can be attributed either to Naspers, Caxton, INP or Johnnic. The only positive development regarding concentration is that the economic compound between Argus and TML is broken; yet Caxton and Johncom are interconnected in 2006 (Derby, 2006).

Another development useful for a lowering of the entry barriers is the population growth in combination with growing literacy among adults. South Africa's population grew from 40.5 million to 45.6 million between 1996 and 2004. Additionally literacy grew: according to Aitchison (2001:3) in 1995 only about 60 percent of South Africa's inhabitants, or 23.5 million, formed the possible audience for the daily newspapers. In 2006, according to South African Media Facts, South Africa has a literate population aged 16 and older of 28,805,000. This represents a growth of the adult literate population, and thus the dailies possible audience, by 22.5 percent. Literacy campaigns lower the entry barriers to the daily newspaper market by adding more people to the reader pool, enabling more papers to conduct their businesses profitably.

Other entry barriers, like the high cost of print production and costs for staff and infrastructure are not examined here. Analysing the development of wages, raw material prices or fuel costs would go beyond this study's aim and reach. 


\section{Distribution}

Distribution in South Africa has not changed significantly since 1990. Most papers are still regional in their appeal, and are seldom distributed in more than one region. There are only a few papers with a multi-regional spreading (The Star, Beeld, Volksblad, Die Burger, Daily Sun). The reasons for the ongoing regional distribution are the same as listed previously. Until now, no publisher from outside has entered the market successfully to publish a national daily. Whether the market is ready for a national daily is open to discussion, yet it is the author's opinion that a national daily is likely to be an outcome of the rising success of tabloids.

\section{Readership}

In the 1990s newspapers had the important task to accommodate themselves with the black majority. For much of the 1990s, newspapers did not achieve this goal. Finally the successful introduction of the Daily Sun demonstrated which mistake had been made for more than ten years: newspapers had not aimed at the emerging middle class, but catered too long for a market with high income and prime education. What was missing, and what the Daily Sun succeeded in, was a paper that aimed directly at the wants and needs of the middle class and the poor. This was proven again by the introduction of the Kaapse Son and the Daily Voice (Van der Walt, 2005). Karl Brophy, executive editor of the Daily Voice, explained the success of the tabloids: '[t]he reason for this success is the fundamental difference between broadsheets and tabloids: broadsheets preach to readers what they should think rather than reflecting what people are thinking' (Van der Walt, 2005).

With the tabloids finally the democratisation and the liberation of Blacks made its way into the market. There are papers catering for different tastes and different audiences now, and all of them operate on sound economic terms.

Of the 19 dailies available in South Africa in 2006 only 17 can be analysed by their readership figures (The Daily Voice is not audited by the South African Advertising Research Foundation (SAARF); the Son is audited as a weekly (its Friday edition is published nationally as a weekly), rendering its readership figure useless for this analysis. The remaining papers are audited by SAARF since 1994).

When looking at their development, it is clearly visible that between 1994 and 2006 more and more people start reading newspapers, as readership almost doubles in that period. This is mainly due to the introduction of the Daily Sun, which alone has a readership of 3,679,000 in 2006; but Beeld, Die Burger, the Daily Dispatch, the Diamond Fields Advertiser, The Herald, the Pretoria News, the Sowetan, Die Volksblad and the Witness also enlarge their readership, plus Isolezwe, which has a growing readership since its launch. The Cape Argus, the Cape Times, The Citizen, the Daily News, The Mercury and The Star have a lower readership than in 1994.

\section{Economic concentration}

Only in 1994, changes in ownership are initiated: in January Argus sells the Sowetan to Prosper Africa, a subsidiary of New Africa Investments Limited (NAIL). Yet Argus retains 
42.5 percent and an overseeing function. The same year, Argus joint holdings with TML are eliminated. This is done in the wake of probably the most important takeover in South Africa's post-apartheid media industry: Independent News Media buys 31 percent of Argus from Anglo and renames Argus into Independent Newspaper Holdings. INP purchases TML's shares in the (Natal) Mercury, the Pretoria News and the Cape Times. According to Jacobs, (1999:4) Perskor also sells its majority shareholding in The Citizen to the Kagiso Trust in 1994.

In 1995, Anglo splits its JCI interests into JCI, Amplats and Johnnic, whereas Johnnic combines the media interests. TML purchases the majority shareholding in the Daily Dispatch. In 1996, the National Empowerment Consortium (NEC) purchases 35 percent of Johnnic, which still holds TML via its subsidiary Omni Media (www.ketupa.net/perskor.htm). In 1997, INP sells its 42.5 percent interest in Sowetan to NAIL.

In 1998, Perskor merges with Caxton \& CTP; Nasionale Pers changes its name to Naspers. In 1999, INP buys out Argus' minority stakeholders to obtain full control. TML sells 30 percent of the Daily Dispatch to Isivumo, a Black empowerment group. In 2000, Naspers reorganises its print media operations under the name Media24. It acquires 50 percent of shares in the Natal Witness. The Evening Post is folded, after having celebrated its $50^{\text {th }}$ birthday the same year.

In 2001 TML becomes Johnnic Publishing and renames EP Herald in The Herald. In 2002 Media24 launches the Daily Sun and INP launches Isolezwe. In 2004, Johnnic acquires 90.5 percent of New Africa publications from NAIL, thus gaining control of the Sowetan, and unbundles its media interests in Johnnic Communications. In 2005, Media24 launches the daily tabloid Nova, and transforms its Kaapse Son into the daily Son. INP launches its Western Cape tabloid Daily Voice. In February 2006 Nova is folded again.

All these transactions, mergers and changes of names lead to the following ownership pattern in 2006:

- INP publishes the Cape Argus, the Cape Times, the Daily News, the Diamond Fields Advertiser, Isolezwe, the Mercury, the Pretoria News, The Star and the Daily Voice

- Naspers publishes Beeld, Die Burger, the Daily Sun, the Son, the Volksblad and the Witness

- Johnnic/Johncom publishes the Daily Dispatch, The Herald and the Sowetan.

- Caxton publishes The Citizen

In terms of concentration not too many changes occurred between 1990 and 2006. Concentration even increased because the independent dailies of 1990 - The Witness and the Daily Dispatch - are now controlled by Naspers and Johncom. The other changes in ownership were, in effect, trades between the big publishers.

The overall circulation figure for the 17 dailies accounted for in the period January-June 2006 is $1,499,968$. Adding the circulation of Son and Daily Voice, which are not included in ABC figures and which were estimated at 50,000 and 60,000, there is a total daily circulation of $1,609,968$ in 2006. INP contributes 591,903 copies to this, or 36.8 percent. Naspers' combined circulation in 2006 is 752,889 , which is correspondingly 46.8 percent. Johncom is with 192,704 copies responsible for 12 percent, and Caxton contributes with The Citizen's 


\section{2,472 the remaining 4.5 percent.}

When comparing these figures to the ones obtained for 1990, a clear trend of increasing concentration catches the eye. The independent publishers have fallen prey, the 19 dailies in 2006 are published by solely four companies. INP publishes the most titles, but Naspers contributes most to the overall circulation. Johncom was able to hold TML's market position, while Perskor's inheritor Caxton has lost market shares.

A positive development is that the ties between Argus and TML via their mother company Anglo have been broken and now all four daily publishers are controlled by different interests (Apart from the Caxton-Johncom bond).

Argus' domination of the English-language market has been reduced, although its successor INP remains the biggest player in that part of the market. Media24 has experienced huge growth in English-language market shares, mostly due to the Daily Sun.

The monopoly of former Nasionale Pers on the Afrikaans-language market has persisted; Media24 is still the only publisher of Afrikaans-language dailies. On the isiZulu-language market, INP holds the monopoly, mainly because INP was the only publisher daring to publish a daily in a native African language.

\section{Editorial concentration}

With F.W. de Klerk's unbanning of opposition groups in 1990, journalists were allowed to write about the ANC again, which eased concentration. But how did editorial concentration develop afterwards? The answer is contradictory.

Certainly the high times of legal constraints are over. But as the analysis has shown, certain apartheid-derived obstacles remain on the statute books. This situation is even worsened by new acts like the Law on Antiterrorism. Yet media freedom enjoys high regard in South Africa and public discussions show that even if the government is sometimes suspected of trying to control the print media, it has certainly not achieved that control. Accordingly, South Africa's media environment is classified as free and takes $58^{\text {th }}$ place in Freedom House's Freedom of the Press 2005 survey (Deutsch Karlekar, 2005:12), ahead of countries like Greece and South Korea.

Political influences affect editorial concentration. ANC officials have attacked the media continuously because they feel that they are criticised too strongly for the reason that the media are still white and racist in their structures and outputs. This critique leads to the question of skin colour of owners and editors of daily papers. When looking at the level of editors, significant change is discernible. Prior to 1990, the only daily where a black editor was possible was The Sowetan. In 1994, the Sowetan still is the only one with a black editor. In 1999, Jacobs writes that six English newspapers are edited by Blacks, and names the Cape Times and Daily News (Jacobs, 1999:13). When looking at the editors in 2006, nine editors have white skin colour and nine a non-white one (No information could be found for the editor of the Cape Times). This is a good sign for less editorial concentration. Of course, in proportion still more Whites are acting as editor than white people are part of the population, but progress has been made and newspaper demographics should be regarded with acknowledging a process of slow adjustment. 
Looking at the level of newspaper ownership, analysis shows that development has run along similar lines. INP is clearly in white hands. Caxton is in the white hands of Moolman and Coburn, who bought into Caxton in 1978 and have since remained control. Naspers is still mainly controlled by its white directors and Afrikaner trusts like Sanlam. The only publisher in black hands is Johncom (yet since the unbundling, Johncom's ownership structure is highly stratified).

As stated above, Johnnic was sold to NEC in 1996. NEC was made up of trade union retirement funds and black business groups like NAIL. Black people are the majority in Johncom's board, while Naspers', Caxton's and INP's boards are predominantly white and male (Government of RSA 2000:19); this situation worsens at senior management level, where all four publishers are mostly white and male. Yet, the capitalisation of the Black Empowerment business Johnnic/Johncom relied on Afrikaner capital and thus saying that it is fully in black hands is not totally right: 'white money undergird[s] Johnnic as it does many of the other "black empowerment" ventures and the new "owners" are subject [to] the dictates of those who supply them with loans' (Government of RSA 2000:28). In effect, this leads to a situation where a clear distinction between black and white capital is no longer possible because of multiple interconnections.

Advertising in South Africa is still mainly oriented at white consumers, for the simple reason that white South Africans still generate and spend a disproportionate large part of disposable income. Papers like the Daily Voice have problems attracting advertisers (Jacobs, 1999:10; van der Walt, 2005), because of its non-white readership. This leads some critics to the conclusion that advertising agencies conduct their business in a racist way (SAHRC, 2000:37).

The so-called English model of newspapers has fallen prey to the 1990s. INP's Chief executive officer John Featherstone explained: 'It's a totally inappropriate way to run modern newspapers, where you have to serve a market you have to provide readers with a package that is acceptable to them' (Jones, 2002:201).

According to Jones (2002:217) this new policy led to an increase of corporate and commercial influences on newspapers' editorials, in turn often triggering critique against the media.

Exemplary, the South African Human Rights Commission (SAHRC, 2000:20f) stated in 2000 that media in South Africa reach only the wealthy part of the population and that poor people are marginalised. This development is a continuation of newspaper's editorial agenda during apartheid, and is thus another incidence pointing to a relatively low level of change in editorial concentration since the democratisation. Only the colour of one of the owners changed, and mining capital was replaced by ketchup capital.

\section{Result}

What do the findings say about the extent of the daily newspaper market in 2006 being shaped by apartheid? The factors speaking for a high determination of the market by apartheid are:

- The ownership of newspaper publishers is still highly concentrated and even increased. Concentration in 1990 was mainly due to the political system of apartheid. 
For at least the same concentration still exists in 2006, apartheid's influence is obvious and cannot be neglected. Additionally, three out of four companies publishing dailies are still held and controlled by white hands. This cannot be explained without apartheid's influence

- Duncan (2003:3) holds the opinion that the ownership structure derived from apartheid was furthered by an increased focus on economics since the democratisation: ' $[t]$ he commercialisation of media was reinforcing the historic disparities in the media inherited from apartheid to create a potent mix of exclusion'

Apartheid's disparities at the level of living standard, education or health affect the general pattern of consumption of South Africans, thus causing to an extent the Whites-preferred-mentality of advertisers

- Although the entrance barriers to the daily market have sunken, a strong influence of apartheid on the market structure is discernible as the participants have an advantage thanks to the conditions they benefited from during apartheid

Yet, there are developments and characteristics in the market that can reverse apartheid's structures:

- Daily newspapers are no longer just produced for the elite, but increasingly for poorer and less educated parts of the society. New tabloids claim rightly that most of its readers were not taken away from established papers, but were recruited in the category of until-then non-newspaper-readers (Harber, 2005). Addressing people from previously untargeted audiences is a step toward less editorial concentration. Perhaps this is the reason why government's critique of newspapers has toned down since the mid-1990s

- There are clearly more black faces in dailies' newsrooms, as we have seen not only due to the Affirmative Action regulations, but also made necessary by the professional imperative. More dailies are edited by Blacks than in 1990, and, even more importantly, with Johncom one of the four daily publishers is chaired by Blacks

- Another strong indicator for a diminishing influence of apartheid is that of the four publishing houses in 1990 just one is still in existence in 2006. Only Naspers got through the sixteen years under analysis without major ownership transformations

- Alongside the publishers the market has internationalised. The fact that international enterprises are publishing newspapers in South Africa seemed impossible during apartheid, the more so in times of 'total onslaught'

Probably one of the biggest rejections from apartheid's daily market is posed by the successful launch of Isolezwe. INP's decision to launch an isiZulu-language daily was not dared by other publishers before, and yet seems so logical today, especially when reminding that isiZulu is South Africa's most wide-spread mother tongue (South African Media Facts, 2006:7).

What can generally be observed is a process of commercialisation. Until 1990, the Afrikaans press was a political press; the English press kept up a profile of relatively independent reporting. With the end of apartheid, both these attitudes were rendered pointless. In the wake of this depoliticisation, the Afrikaans press turned towards a market oriented view of its 
operations. The English press said goodbye to its separation of management from editorial. Of course, publishing newspapers was already a commercial venture before, yet the political transition deepened the market orientation, following a global trend of commercialisation of media.

When comparing the facts speaking for a strengthening or a weakening influence of apartheid in the South African daily newspaper market in 2006, the author concludes that apartheid's influence is weakening gradually since 1990. Most of apartheid's market characteristics have disappeared; others like the high economic concentration are still present. But then, economic concentration is typical for most print media markets all over the world. Also, the multiple divisions between population groups, still discernible in specific papers' readership or editorial appeal, (or problems to attract advertisers) were surely created by colonialism and apartheid in the first place. Yet today these divisions are no longer imposed by the state, but by a market rationale. The influence of apartheid on the daily market is still discernible, but diminishing steadily.

The author holds the opinion that further development is at hand, and that the market itself will take care of that transformation. The continuing success of new tabloids aiming at a new readership has shown that even the orientation with an elitist white readership is transforming. If the market is left to itself and the overall economic development is positive, transformation of the structures remaining from apartheid seems possible and probable.

Writers like Kolbe argue that the market is less attractive than it was under apartheid (Kolbe, 2005:247) because it is turning towards less prosperous customers; and perhaps the invention of tabloids is just a return of the extra editions, dividing the market in a tabloid part for a poor black readership, and a broadsheet part for a prosperous white readership. But in the author's opinion, the market is coming to terms with the social and political reality of South Africa, enhancing attention towards black readerships, which are less prosperous now because of the ill effects of apartheid. Besides, the concept of tabloids aimed at a less intellectual readership is not unique to South Africa.

\section{About the author}

Author: Tobias Bauer is Public Information Assistant at the United Nations World Food Programme (WFP) in Berlin/Germany.

\section{Contact details}

E-mail address: tobias.bauer@wfp.org (work), bauer.tobias@yahoo.de (private)

Mailing address: Tobias Bauer, Lahnstrasse 87, 12055 Berlin, Germany.

(The full version of this study, including an analysis of the single publishers, was published 2007 under the title: 'Liberation and the media: the development of the South African daily newspaper market since the end of apartheid', Norderstedt/Germany: Books on Demand, 2007, ISBN: 9-783833-497254).

\section{References}

Aitchison, J. 2001. Reading and writing the new South Africa: literacy and adult basic education and training in South Africa. In: Stilwell, C., Leach, A. \& Burton, S. (Eds.): Knowledge, information and development: an African perspective. Pietermaritzburg/South Africa: University of Natal. 
Constitution of the Republic of South Africa 1996, $§ 9 / 2$.

Derby, R. 2006. Is Caxton gunning for Johncom? Accessed: 2006-10-26:

http://business.iafrica.com/news/599337.htm

Deutsch Karlekar, K. (Ed.) 2005. Freedom of the press 2005. A global survey of media independence. New York/USA: Rowman \& Littlefield.

Duncan, J. 2003. Another journalism is possible: critical challenges for the media in South Africa: Freedom of Expression Institute.

Freedom of Expression Institute. 1995. Who owns who in the South African print media. Accessed: 2006-09-08: http://www.fxi.org.za/archive/Linked/update/9505/insert.html

Government of RSA. 2000: Promoting media development and diversity, and access to information in South Africa. The Media Development and Diversity Agency, a Draft Position Paper.

Hachten, W. \& Giffard, A. 1984. The press and apartheid. repression and propaganda in South Africa. Wisconsin/USA: Unversity of Wisconsin Press.

Hahne, K. 2002. Affirmative Action im neuen Südafrika. Munich/Germany: Akademischer Verlag Muenchen.

Harber, A. 2005. Rich diet at bottom of trough. Business Day. 2005-04-12.

Jackson, G. 1993. Breaking story: the South African press. Boulder/USA: Westview Press.

Jacobs, S. 1999. Tensions of a free press: South Africa after apartheid. USA: Harvard University.

Jacobs, S. 2002. Mapping the public sphere after 1994: the media set-up. In: African and Asian Studies, Vol.1 (4):279-302.

Jones, A. 2002: The press in transition. Hamburg/Germany: Deutsches Übersee Institut.

Kolbe, H.R. 2005. The South African print media: from apartheid to transformation. Doctoral thesis submitted at the University of Wollongong/Australia.

Lewis, J. D. 2001. Policies to promote growth and employment in South Africa. Informational discussion papers on aspects of the economy of South Africa. World Bank.

Lutchman, J. (Eds): State of the nation: South Africa 2004-2005. Cape Town/South Africa: HRSC Press.

Maake, N. 2002. Publishing and perishing: books, people and reading in African languages in South Africa. In: Evans, N.\& Seeber, M. The politics of publishing in South Africa.

London/England: Holger Ehling Publishing. 
Märlender, P. 2000. Die Bedeutung der Presse im Transitionsprozeß Südafrikas.

Hamburg/Germany: Institut für Afrika-Kunde.

Muller, J. 1987. Press houses at war: a brief history of Nasionale Pers and Perskor. In:

Tomaselli, K., Tomaselli, R. \& Muller, J. (Eds): The press in South Africa. London: Currey.

Ndlela, N. 2003. Challenges and prospects for press freedom. Comparative perspectives on media laws in Zimbabwe and South Africa. Doctoral thesis submitted at the University of Oslo/Norway.

SAHRC. 2000. Faultlines: inquiry into racism in the media. Accessed: 2006-11-06: http://www.sahrc.org.za/faultlines.PDF

South African Media Facts. 2002. OMD: Johannesburg/South Africa. These documents rely on data provided by AC Nielsen's AdEx (2002).

South African Media Facts 2006, OMD: Johannesburg/South Africa. These documents rely on data provided by Nielsen Media Research's Multimedia (2006).

Southall, R. 2004. Black empowerment and corporate capital. In: Daniel, J., Southhall, R. \& Lutchman, J. (Eds): State of the nation: South Africa 2004-2005. Cape Town: HRSC Press.

Tomaselli, K. \& Tomaselli, R. 1987. The political economy of the South African press. In:

Tomaselli, K., Tomaselli, R. \& Muller, J. (Eds): The press in South Africa. London: Currey.

Van der Walt, J. 2005. Another day, another tabloid. Accessed: 2006-10-13:

http://www.iol.co.za/index.php?set_id=1\&click_id=13\&art_id=vn20050417094232267C1437 44 van der Walt 2005.

Vapi, X. 1999. Obstacles and challenges facing the media in South Africa. In: KonradAdenauer-Stiftung: Seminar Report. Politics and the media in Southern Africa.

Johannesburg/South Africa. 